\title{
Yeryüzüi ile Yeni Bir İlişki: Biyosantrizm ve Derin Ekoloji
}

\section{A New Relationship with The Earth: Biocentrism and Deep Ecology}

\author{
Ayşe Bilge Demir ${ }^{1}$
}

'Yüksek Lisans Öğrencisi, Ankara Üniversitesi, Sistematik Felsefe ve Mantık Anabilim Dalı, Ankara, Türkiye

\section{ORCID: A.B.D. 0000-0001-7592-3051}

Sorumlu yazar/Corresponding author: Ayşe Bilge Demir,

Ankara Üniversitesi, Sistematik Felsefe ve Mantık Anabilim Dalı, Ankara, Türkiye E-mail/E-posta: aysebilged@gmail.com

Başvuru/Submitted: 26.11.2019 Revizyon Talebi/Revision Requested: 25.03.2020

Son Revizyon/Last Revision Received: 28.03.2020

Kabul/Accepted: 30.03 .2020

\section{Atıf/Citation:}

Demir, Ayse Bilge. (2020). “Yeryüzü ile Yeni Bir İlişki: Biyosantrizm ve Derin Ekoloji" Felsefe Arkivi-Archives of Philosophy, 52: 97-111. https://doi.org/10.26650/arcp2020-006

\section{ÖZET}

Bu çalışmada derin ekolojinin önerdiği biyosantrik bir perspektife yerleşme gereği ele alınmıştır. İnsan-doğa ilişkisinin tarihsel seyri ele alınmış, bu ilişkinin tarafları arasındaki yarılmanın niçin ve ne zaman ortaya çıkığı incelenmiştir. Çevre sorunlarının şiddetini artırması nedeniyle doğanın yalnızca bilimin değil aynı zamanda felsefenin de konusu edilmesi ihtiyacı, 1970li yıllarda çeşitli ekofelsefe geleneklerinin doğuşuna yol açmıştır. Bu yaklaşımlar arasında derin ekolojinin radikal bir konumu işgal ettiği öne sürülmüştür. Derin ekolojinin doğa ile insan ilişkisindeki soruna dair tespitleri ve bu ilişkideki iyileşmenin nasıl sağlanabileceğine dair önerileri ve modern akıl merkezciliğe yönelik eleştirileri ele alınmıştır. Derin ekolojik yaklaşımın pratik karşıı̆ı̆ının imkânı sorgulanmıştır. Bu yaklaşıma getirilen eleştiriler kısaca ele alınmış ve bu eleştirileri derin ekolojik yaklaşımın iyileştirilmesi için sunulan reçeteler olarak görmemiz önerilmiştir. Çevre-merkezci yaklaşımların önerdiği gibi insan-doğa ilişkisini sömürücü olmayan karakterdeki bir toplumsallıkta kurma çabasının, biyosantrizmi öteleyerek değil, fakat bireysel yaşamlarımızda doğa ile ilişkimizi derin ekolojik ilkeler doğrultusunda düşünmek suretiyle mümkün olduğu savunulmuştur. Bu sayede sığ ekolojilerin insan faydası temelinde kurulan ilkelerinden uzaklaşmanın yanı sıra doğa ve çeşitliliğin gerçek doğasının kavranması da mümkün olacaktır. Derin ekolojik ilkelerde politikaların değişmesine ve sorumluluğa yapılan vurguları, toplumsal bir dönüşümün ardındaki etik dünya görüşünü inşa etme çabaları olarak düşünmek gerekir. Sonuçta derin ekoloji tarafından sistemleştirilen biyosantrizmin, hem insanlar arasındaki hem de insan ile insan olmayan varlıklar arasındaki sömürü ve tahakküm ilişkilerinin sonlanması adına yapıcı öneriler sunduğu öne sürülmüştür.

Anahtar Kelimeler: Derin ekoloji, ekofelsefe, Arne Naess, ekosofi, biyosferik eşitlik, canlı merkezcilik

\section{ABSTRACT}

This study discusses the necessity to take a biocentric perspective as suggested by deep ecology. The historical course of the relationship between humankind and nature is discussed, and the timing of and the reasons for the separation between the parties in this relationship is investigated. With the increase in severity of environmental problems, the necessity to include nature as well as science in philosophical discussions resulted in the emergence of various eco-philosophy traditions in the 1970s. Among these approaches, deep ecology is claimed to 
occupy a radical position. Evaluations of deep ecology regarding the problem in the relationship between humans and nature, suggestions on how this relationship could be improved, and criticism of modern mentality are discussed here. The practicality of a deep ecological approach is questioned. Criticism of this approach is briefly mentioned and proposals are made as prescriptions for the improvement of the deep ecological approach. As environment-centric approaches suggest, the effort to establish the human-nature relationship in a non-exploitative collectivity is argued to be possible not by distracting biocentrism but by evaluating our relationship with nature in our individual lives according to ecological principles. Therefore, it will be possible to comprehend the true quality of nature and diversity in addition to moving away from the principles of shallow ideologies based on human benefit. According to deep ecological principles, the emphasis on the change of policies and responsibilities should be regarded as efforts to establish an ethical perspective behind social transformation. In conclusion, this study argues that biocentrism systematized by deep ecology offers constructive suggestions for ending exploitation and domination in the relationship between humans, and humans and other creatures.

Keywords: Deep ecology, ecophilosophy. Arne Naess, ecosophia, biospheric equality, biocentrism

\section{Giriş}

Felsefenin başlangıcı MÖ 6.yüzyıla dayanırken, ekofelsefenin doğuşu 1970li yıllara dayanır. Bunun anlamı ekosistemin felsefenin bir problemi olarak görülmesinin bu senelere kadar bir ihtiyaç halini almamış olmasıdır. Felsefenin en önemli işlevlerinden biri, insanın dünyayı kavrayışındaki temel varsayımları sorgulamaktır. Bu anlamda ekofelsefe de insanın ekosistem ile kurduğu ilişkinin boyutlarını inceler. Henüz yeni bir soruşturma alanı sayılabilecek ekofelsefe, aynı zamanda ekosistem ile kurulan ilişkinin tarihini de temel perspektifi çerçevesinde yeniden yazar. Sözgelimi antroposantrik bir perspektif, bu ilişkinin insanın ilgi ve çıkarlarına göre biçimlendiğini, biyosantrik bir perspektif ise insanın ilgi ve çıkarlarının ekosistem ile ilişkiyi dışarıdan biçimlendirici bir nitelik taşımadığını öne sürer. Antroposantrizm gücünü ve ilkelerini Descartes’ın yaptığı 'özne ve diğerleri' ayrımından alırken, biyosantrizm gücünü ve ilkelerini, insanın uygarlığı yaratmasından evvel dünya ile kurduğu parça-bütün ilişkisinden alır. Antroposantrizm insanı doğanın dışında konumlandırır ve doğayı insanın kullanımı için gözetmek gerektiğini düşünür. Fakat bu yaklaşım çevre kirliliği, türlerin yok oluşu vd. gibi çevre problemlerini azaltmadığı gibi, bu problemlerin şiddetini daha da artırmasına yol açmıştır. Çünkü doğayı insanın kullanım alanı olarak görmek ve bu sebeple korumak, doğa ile kurulan ilişkinin etik boyutunu gözden kaçırmakta, insanı etkin ve doğayı edilgin olarak tanımlamaktadır. Bu durum doğa ile kurulacak ilişkinin yeni bir merkezden ele alınması gereğini doğurmuş ve canlılık merkezli (toprak etiği, türsel olmayan etik, derin ekoloji) ve çevre merkezli (toplumsal ekoloji, ekofeminizm) yaklaşımların doğuşuna ortam hazırlamıştır.

Bu çalışmada özel olarak derin ekoloji üzerinde durulacak olsa da bunun nedeni derin ekolojinin diğer çevre etiği yaklaşımlarına göre önceliğini vurgulamak değildir. Bu çalışmanın amacı daha ziyade, derin ekolojinin radikal tavrı üzerinden dünyaya bakışımızı biyosantrik çerçeveden yeniden oluşturmanın gereğini vurgulamaktır. Derin ekoloji bize hem doğayla olan ilişkimizde hem de insan olmanın anlamında radikal bir değişiklik önerir. Ancak bu radikal değişiklik sayesinde çevre sorunlarının iyileştirilmesi ve bunun da ötesinde dünya ile bütüncül bir ilişki kurmak mümkün olur. 


\title{
2. İnsan-Doğa İlişkisinin Tarihsel Seyri
}

10 bin yıl evvel tarımın ortaya çıkmasından önce avcı toplayıcı insanlar, çok uzun zamanlar boyunca dünya ile bizim anlamakta son derece zorlandığımız türde bir ilişki kurmuşlardır. Bu insanlar mekânı ve zamanı ölçülebilir niteliklere bölme gereği olmaksızın, varlıklara isim vererek onları bir anlama hapsetmeksizin yaşamışlardır. Modern terapinin önerdiği burada ve şimdide yaşamaya odaklanma teknikleri, onlar için çaba gösterilmeyecek doğal bir tavırdır. Geçmiş ve gelecek ayrımını oluşturan türde bir zaman algısının meydana gelmesi, ekinleri ekme, işleme ve toplama gereği nedeniyle tarım ile birlikte ortaya çıkmış bir zorunluluktur. Aynı şekilde dilin ortaya çıkması ve düşüncenin sembolleştirilmesi insanlık tarihi için henüz yeni bir oluşum sayılabilir. Sayı kavramı da toprağın mülkiyet nesnesi olarak görülmediği bir dönemde tümüyle anlamsızdır. Dilin, sayının ve zamanın ortaya çıkışı, dünya ile kurulan ilişkideki yabancılaşmanın başlangıcıdır. Bu araçlar sayesinde insan ile insan olmayan varlıklar arasındaki ilişki, bir hiyerarşi ilişkisine dönüşmüştür. ${ }^{1}$

Yabanıl insanın doğayla, kendisini ondan ayırmadan kurduğu bu ilişki biçiminin aklın gelişiminin yetersizliği ile ilgili olmadığına dair yeni çalışmalar ortaya çıkmaktadır². Bu çalışmalar avcı toplayıcı insanların beyin kapasitesinin bugün bizim sahip olduğumuz kapasiteye eşdeğer olduğunu öne sürer:

\begin{abstract}
"Zekâ teorisi tamamen avutucu ve ırkçı bir rasyonelleştirmedir: Yeterince zeki olan insanların ille de bizimki gibi bir yaşam kuracaklarını varsaydığı için avutucudur. Günümüzde ilkel yaşam biçimini tercih eden insanların, başka bir yaşamı sürdüremeyecek kadar aptal olduklarını varsaydığı için de ırkçıdır. Bu mantık şunu demeye getiriyor; eğer o insanlar yeterince akıllı olsalardı, onlar da bizler gibi asfalt, ağaç testeresi ve hapishane icat ederlerdi."”
\end{abstract}

Yabanıl insanın zekâsındaki gelişmemişliğe ve sürekli savaş halinde yaşadıklarına dair yanılgı, Batı biliminin ve tarihinin gücünü ve meşruiyetini sağlama almasına yol açmıştır. Böylece bilimin, ilerlemenin tek ve gerçek aracı olduğu inancı güç kazanmış ve bilimsel ilerlemenin yol açtığı zararlar bu inanç sayesinde görmezden gelinebilmiştir.

İnsan ile dünya arasındaki ilk kopma, tarımın ve mülkiyetin ortaya çıkması ile yaşanmıştır. Böylece insanlar arasındaki bütünlük ve Biz algısı da zedelenmiş ve hiyerarşiye dayalı bir toplumsal örgütlenme doğmuştur. Rousseau’nun da öne sürdüğü gibi "Bu toprak benimdir” diyerek ve başkalarını da bu iddiaya inandırarak yaratılan mülkiyet, efendilerin ve kölelerin doğuşuna zemin hazırlamıştır.

İnsan-doğa ilişkisinin tarihsel seyrini tüm boyutlarıyla ortaya koymak bu çalışmanın içeriğini oluşturmadığından genel paradigma değişimlerine işaret etmek amacıyla tarım devriminden

\footnotetext{
John Zerzan, Gelecekteki İlkel, çev. Cemal Atila, (İstanbul: Kaos Yayınları, 2018).

Bkz. John Fowlet ve Thomas Wynn tarafından yürütülen arkeolojik araştırmalar.

Zerzan, Gelecekteki İlkel, 266.
} 
doğrudan uygarlık tarihine atlama gereği duyuyorum. Bu belki de sakıncalı bir tutum. Fakat uygarlığın doğuşu ile ilgili Freud'un şu sözü üzerinde durmanın bu tutumu haklılaştıracağını düşünüyorum: "Uygarlık bana, iktidar ve baskı araçlarının mülkiyetini elde etmenin yöntemini kavrayan bir azınlık tarafından, direnen bir çoğunluğa uygulanan bir olguymuş gibi görünüyor.” Tarımın ortaya çıkışı ile uygarlığın doğuşu arasında doğrudan bir ilişki vardır.

Antik Yunan, Batı felsefesinin doğduğu ve bundan sonraki gelişim seyrini belirlediği temel bir uğraktır. Pre-Sokratik filozofların doğayı düşünüşü ondaki temel ilkeyi keşfetme arzusuna dayanır. İnsan ile doğa arasındaki ilk esaslı kopuş burada karşımıza çıkar. Çünkü doğa, felsefenin konusu haline gelmiş, tarım sayesinde yaratılan sayı, dil, zaman gibi kategoriler ilk defa varlığın bütününe uygulanmaya başlamıştır. Doğa filozoflarının düşünceleri Antik Yunan'da biri Pytagorasçllı öteki ise Aristotelesçilik olmak üzere 2 önemli felsefenin doğuşuna ortam hazırlamıştır. Pytagorasçılık antroposantrik anlayışın ilk savunucusu olmuş, ruh göçüne olan inancı nedeniyle diğer hayvanların yenmemesi gerektiğini öne sürmüştür. Aristoteles ise varlıklar arasında doğadan kaynaklanan bir hiyerarşi olduğunu öne sürmüş ve Orta Çağ’dan geçerek bugün hâkim paradigmayı şekillendirmede önemli bir paya sahip olmuştur. Aristotelesçilikten ve Hristiyanlıktan beslenen Orta Çă̆ felsefesinin doğaya karşı tutumunu en iyi, bu felsefenin bir temsilcisi olan Thomas Aquinas'in düşüncelerinde görürüz:

"Bir şeyi amacına uygun olarak kullanmakta hiçbir günah yoktur. Dünya düzeni öyledir ki, kusurlu olanlar kusursuz olanlar içindir... Bitkiler gibi sadece yaşayan şeylerin bütünü hayvanlar için ve bütün hayvanlar da insanlar içindir. Bundan dolayı filozofun belirttiği gibi, insanların bitkileri hayvanların iyiliği için ve hayvanları insanların iyiliği için kullanması yasak değildir." ${ }^{5}$

Modern döneme geldiğimizde Kopernik'in Güneş merkezli evren modeli ile beraber, Aristoteles'ten beri hüküm süren insan merkezciliğin ortadan kalkmış olacağını düşünmek mantıklı görünüyor. Fakat bir kez daha dünyanın mantıklı olana göre dönmediği gerçeği ile karşılaşıyoruz. Bilimsel gelişmeler bu dönemde, insanın kendisini geometrik dille yazılmış kullanma kılavuzuna göre evreni avuçları içine alabilecek meşru bir kullanıcı olarak görmesine yol açmıştır. Bacon, bilimsel yöntem sayesinde elde edilecek bilginin doğanın hükümdarı olmak adına sağlayacağı sonsuz faydadan söz ederken, Descartes bu bilginin yalnızca insan varlıklarına açık olduğunu öne sürmüştür. Bu dönemde sayıların dili, evrenin dili olarak görülmeye başlanmıştır. Eğer evren bu dili kullanmıyorsa, onun konuşmadığı ve sessiz kaldığı varsayılmıştır. Descartes ile birlikte ortaya çıkan bu kavrayış, bugün dünyayı düşünüşümüzde büyük ölçüde etkilidir. Bilimsel ilerlemeye ve insan aklına duyulan sonsuz güven, doğanın ve insan haricindeki canlıların sömürgeleştirilmesine zemin hazırlamıştır. $\mathrm{Bu}$ anlayıştan itibaren tarım devrimi ile doğa ve insan arasında açılan yarık kapanması oldukça zor şekilde genişlemiştir. Orta Çağ a hâkim din kurumu hâlihazırda, varlıkların

4 Sigmund Freud, The Future of an Illusion, (New York: 1955), 10.

5 Thomas Aquinas'ın Filozof diyerek kastettiği kişi elbette Aristoteles'tir. Bkz. Thomas Aquinas, The Summa Theologica, Translated by Fathers of The English Dominican Province, Erişim 30 Nisan 2020, (http://www. documentacatholicaomnia.eu/03d/1225-1274,_Thomas_Aquinas,_Summa_Theologiae_[2],_EN.pdf) . 
insanın kullanımı için mevcut bulunduğunu öne sürüyordu. Bu iddia Modern dönemden itibaren artık bilimin ve aklın da desteğini kazanmış oldu. Böylece insanın yeryüzünün sahibi olduğu düşüncesi dört bir yanından kuşatılmış oldu. Bu durumda aksi bir iddia, yani insanın yeryüzünün yalnızca bir ögesi olduğu iddiası, yalnızca saçma değil aynı zamanda gülünç bir yapıya büründürüldü.

Bilimsel ilerlemeye duyulan güven, aklın iddialarının yalnızca bilimsel olma koşuluyla kabul görmesi sonucunu doğurdu. Pozitivizm ile birlikte bilimsel olmayan düşünceler metafizik ilan edilip bir köşeye atıldı. Fakat burada gözden kaçırılan şey, bilimsel olmanın ne anlama geldiğine dair nesnel bir ölçünün olamayacağıdır. 1962 yılında Kuhn, Bilimsel Devrimlerin Yapısı adlı çalışması ile bilgiye bilimsel olma niteliğini yükleyen şeylerden birinin de bilim insanları topluluğunun inanç ve kanaatleri olduğunu ortaya koydu. Bu, bilimsel ilerleme düşüncesine indirilmiş büyük bir darbedir. Görecilikle suçlanan fakat bu suçlamayı her firsatta reddeden Kuhn, bilimsel kuram seçiminin evrensel ölçülere vurulamayacak bir işlem olduğunu öne sürüyordu. Kuram seçimindeki rasyonellik matematiksel ölçülere vurulamaz. Daha iyi olan kuramı seçmeye yarayan ölçütler birer kural gibi değil, daha çok değer yargıları gibi işler. ${ }^{6}$

Bugün doğanın insanın sömürüsünü bekleyen bir nesne olduğu iddiasına modern dönemde olduğu kadar kesin bir şekilde inanıyor değiliz. Çevre sorunlarının görmezden gelinemeyecek bir raddeye ulaşmış olması bize bir şeylerin yanlış gittiğini düşündürüyor. Bu nedenle ekosistemi bilimin alanından felsefenin alanına taşımanın ya da en azından felsefeyi de bilimin ekosistemi ele alış tarzında etkin kılmanın gerekli olduğunu görüyoruz. İnsan olmayan varlıklar ve bir bütün olarak doğa ile kurduğumuz ilişkinin kusursuz bir ilişki olmadığı artık açık. Bu ilişkiyi düzenlemeye veya değiştirmeye yönelik çeşitli yaklaşımlar ortaya çıkmıştır.

\section{3. Çevre Etiği Yaklaşımları}

$\mathrm{Bu}$ yaklaşımları insan merkezli (antroposantrizm), canlı merkezli (biyosantrizm) ve çevre merkezli yaklaşımlar olarak 3 ana eksende incelemek mümkündür. ${ }^{7}$ İnsan merkezli yaklaşım, doğayla kurulan ilişkiyi insanın ön planda olduğu bir çerçeveden ele alır. Başka deyişle bu yaklaşım içerisinde, insan ile insan olmayan varlıklar arasındaki bir çatışma durumunda öncelik insanın çıkarlarına verilir. İlişkideki etik boyut da böylece insan merkezli bir çerçeve ile sınırlandırılır. Sözgelimi hayvanları ve hayvansal ürünleri yemenin protein alımı için zorunlu olmadığını öne süren çalışmalar ortaya çıktığında bile bu ürünleri tüketmeye devam etmekte etik bir problem görülmez. Çünkü insan varlığı, diğer türlere göre hiyerarşik bir üstünlüğe ve onun damak zevki, diğer türlerin yaşama isteğinin üstünde bir değere sahiptir. Bu yaklaşımdaki probleme Richard Routley, 'son insan' örneği ile işaret etmiştir. Routley, gezegende son insan olarak kaldığımızı ve elimizde kendimizle beraber tüm gezegeni yok edecek bir butonu tuttuğumuzu varsaymamızı ister ve bu durumda butona basmakta etik olarak yanlış herhangi bir şeyin olup olmadığını sorar. Ona göre antroposantrik tutum, bu şartlar altında butona basmanın neden yanlış olduğunu

6 Nilüfer Kuyaş, Thomas S. Kuhn'un Bilimsel Devrimlerin Yapısı adlı kitabına sunuş, (İstanbul: Kırmızı Yayınları, 2005), 47.

7 Fehmi Ünsalan, “Küresel Ekolojik Kriz ve Felsefe: Paradigmadan Kaçış Mümkün Mü?”, Alternatif Politika 1 (2019): 95. 
açıklayamaz. ${ }^{8}$ Çünkü antroposantrik tutum doğaya, onun kendinde değeri açısından değil, kullanım değeri açısından yaklaşır. Tüm sınırlılıklarına rağmen bu yaklaşım ilk defa çevre sorunlarına dair bir sorumluluk alanı belirlemesi bakımından son derece önemlidir.

Routley'in örneğindeki butona basmanın yanlışlığını açıklamak için canlı merkezli ve çevre merkezli yaklaşımlar ortaya çıkmıştır. Canlı merkezli yaklaşım (biyosantrizm), insan ile insan olmayan varlıklar ve gezegen arasındaki ilişkiyi modern akıl merkezciliği bırakarak kurmak gerektiğini düşünür. "Daha zeki olmak bir insana başka insanları kendi amaçları doğrultusunda kullanma hakkı vermiyorsa, nasıl olur da genel olarak insanlara insan olmayanları sömürme hakkı verebilir?"' şeklindeki kayda değer soru gün yüzüne çıkar. Yaşayan varlıklar arasındaki ilişkinin bir parça-bütün ilişkisi olduğu ve her parçanın özgül farklılıklarına rağmen eşit derecede değerli olduğunu savunulur. Biyosantrik yaklaşımlar Peter Singer'ın türsel olmayan etiği ve Arne Naess'in derin ekolojisi gibi çeşitli kuramları içerse de bunların her birinin temel anlayışı, Aldo Leopold'un toprak etiği düşüncesine dayandırılabilir. Leopold, doğanın bütün olarak bir tür bilince sahip olduğunun, bu bilincin akılsal bilinci kapsasa da daha geniş bir bilinçlilik olduğunun ve bu yüzden doğanın kendinde bir değere sahip olduğunun görülmesi gerektiğini savunur. ${ }^{10} \mathrm{Bu}$ nedenle toprağı da içine alacak yeni bir etik yaklaşım geliştirilmelidir. Doğanın içindeki tüm varlıklarla beraber bütüncül bir özne olarak kabul edilmesi gereklidir. Dolayısıyla yalnızca insanlara değil, tüm varlıklara karşı ahlaki bir tutum göstermek, böyle bir tutum için kendimizi yetiştirmek ve değiştirmek zorunludur.

Çevre merkezli yaklaşım ise biyosantrizmi çevresel sorunların kaynağındaki toplumsal yapılanmayı görmezden gelmekle ve sorunun tek kaynağını insan psikolojisine dayandırmakla suçlar. Çevre sorunları yalnızca etik değil aynı zamanda politik de bir sorundur; çünkü çevre doğa ile insan arasındaki dönüştürücü ilişki ile karakterize olur. Bu yaklaşım içerisinde Bookchin, toplumsal ekolojinin savunuculuğunu yapmış ve doğayı da içine alacak bir toplumsal yapılanmanın inşasını gerekli görmüştür. ${ }^{11}$ Gene bu yaklaşım içerisinde ekofeminizm, sorunun ataerkil toplumsal yapılanmadan kaynaklandığını ve çözümün bu yapılanmayı değiştirmekten geçtiğini ortaya koymuştur.

Çevre merkezli yaklaşımların sorunu politik çerçevede ele alması her ne kadar önemli bir adım ise de bu yaklaşımın gerekli gördüğü dönüşümlerin doğa- insan ilişkisinde radikal bir değişikliği gerektirdiği açıktır. Çevre merkezli yaklaşıma, biyosantrizmi öteleyerek ulaşmaya çalışmak, antroposantrik tutumu sürdürmekten başka bir işe yaramayacaktır. Başka deyişle öncelikle doğa ile olan ilişkimizde yeni bir konuma yerleşmemiz gerekir. Ancak bu konuma yerleştikten sonradır ki toplumu yeniden düzenleyerek birtakım değişikliklere gitmek mümkün olur. Nasıl ki paradigma değişimi bir sürecin değil bir devrimin ürünüdür; biyosantrik bir perspektif için de eski kavrayışları geride bırakmak, eski kavrayışın (antroposantrizm) cevaplayamadığı sorularla yüzleşmek gerekir.

8 Katie McShane, "Environmental Ethics: An Overview”. Philosophy Compass 413 (2009): 407-408.

9 Peter Singer, Hayvan Özgürleşmesi, çev. Hayrullah Doğan, (İstanbul: Ayrıntı Yayınları, İstanbul, 2005), 43-44.

10 Aldo Leopold, A Sand County Almanac: With Essays on Conservation From Round River, (New York: Ballantine Books, 1970), 147.

11 Murray Bookchin, Social Ecology and Communalism, (Edinburg: AK Press, 2006), 44. 


\section{Radikal Bir Biyosantrik Tutum Olarak Derin Ekoloji}

Derin ekoloji yaklaşımı 1962'de Rachel Carson tarafından yazılan Silent Spring kitabı ile kendisini göstermeye başlamıştır. Carson'ın fikirleri, temel varsayımlarını ortaya koyarak derin ekolojiye yön vermiştir. Fakat bu yaklaşımın ana ilham kaynağı Leopold'ün toprak etiği düşüncesidir. ${ }^{12} \mathrm{Bu}$ yaklaşıma en önemli katkıyı Norveçli filozof Arne Naess yapmıştır. 1972 yılında yapılan Üçüncü Dünyanın Geleceği Konferansında ilk kez öne sürdüğü sığ ekoloji- derin ekoloji ayrımı ile derin ekolojinin sistemleştirilmesinde etkili olmuştur. Arne Naess' in yanı sıra Bill Devall, George Sessions ve Beat kuşağı şairlerinden Gary Snyder da derin ekolojiden yana tavır almışlardır.

Naess, sığ ekoloji ve derin ekoloji ayrımını tabloda görüldüğü gibi karşılaştırmaktadır: ${ }^{13}$

\begin{tabular}{|c|c|}
\hline Sığ Ekoloji & Derin Ekoloji \\
\hline Doğadaki çeşitlilik, insanlar için değerli bir kaynaktır. & Doğadaki çeşitlilik, kendisi için değer taşır. \\
\hline $\begin{array}{c}\text { İnsan için olmayan değerden söz edilemez. } \\
\text { Bitki türleri tarım ve tıpta insanların yararına kullanıldığı } \\
\text { için değerlidir. }\end{array}$ & $\begin{array}{c}\text { Değeri sadece insan için görmek, ırkçı bir önyargıdır. } \\
\text { Bitki türleri korunmalıdır. Çünkü onların değeri } \\
\text { insanlan yararına olmakta değil, kendi özlerindedir. }\end{array}$ \\
\hline $\begin{array}{c}\text { Kirlenme eğer iktisadi gelişme ve büyümeyi } \\
\text { engelliyorsa durdurulmalıdır. }\end{array}$ & $\begin{array}{c}\text { Kirlenmenin durdurulması iktisadi gelişmeden önce } \\
\text { gelir. }\end{array}$ \\
\hline $\begin{array}{c}\text { Gelişen toplumlardaki nüfus artışı, doğal dengeyi } \\
\text { tehlikeye sokmaktadır. }\end{array}$ & $\begin{array}{c}\text { Dünya nüfusunun artışı doğal dengeyi tehdit } \\
\text { etmektedir. Ama gelişmiş ülkelerin nüfusu ve faaliyetleri } \\
\text { daha tehlikelidir. }\end{array}$ \\
\hline $\begin{array}{c}\text { Kaynak, insan için yararlı olan anlamına gelir. } \\
\text { İnsanlar yaşam seviyelerinde geniş çaplı bir gerilemeye razı } \\
\text { olmazlar. }\end{array}$ & $\begin{array}{c}\text { İnsanlar aşırı gelişmiş milletlerin yaşam seviyesinin } \\
\text { düşmesine } \\
\text { değil, genel yaşam niteliğinin düşmesine razı } \\
\text { olmamalıdırlar. }\end{array}$ \\
\hline Doğa acımasızdır ve böyle olması gereklidir. & \begin{tabular}{c} 
İnsanlar da acımasıdır, ama böyle olması gerekmez. \\
\hline
\end{tabular}
\end{tabular}

Sığ ekolojik yaklaşımın ilkeleri antroposantrik tutumun ürünüdür. Bu yaklaşıma göre doğadaki çeşitlilik, insan için sağladığı fayda bakımından değerli görülür. Oysa derin ekoloji, insan merkezciliğin çeşitliliğin gerçek yapısını kavramada yetersiz olduğunu düşünür. Sığ ekolojinin perspektifinden baktığımızda, çeşitliliğin insan faydasını tehdit ettiği durumda müdahale edilir. Sözgelimi kıyılarda çoğalan aslan balıklarının, insanların tükettiği balıkların soyunu tehdit etmesi durumunda duruma müdahale edilir ve aslan balıkları oradan 'temizlenir'. Sığ ekolojide insan kendisini ekosistemin bir parçası olarak değil, onun düzenleyicisi olarak görür. Aslan balığı istilası yalnızca insan aleyhine değil, diğer balıklar aleyhine de bir tehdit oluşturabilir. Fakat derin ekolojik yaklaşımda bu duruma aslan balıklarını öldürerek müdahale etmek kabul edilebilir bir durum değildir. İnsan, doğanın dengesini düzenlemede söz sahibi değildir. Derin ekolojik yaklaşım öncelikle insandan kaynaklanan sorunların ortadan kaldırılmasını hedefler. $\mathrm{Bu}$ hedefin gerçekleştirilmesi durumunda doğanın kendi dengesini bulacağı düşünülür. Derin ekolojide doğa ile bütünleşmeye dayalı bir ahlaki değerlendirme söz konusudur. ${ }^{14}$

12 George Session, Deep Ecology For The 21st Century, (Boston: Shambhala, 1995).

13 Günseli Tamkoç, "Derin Ekolojinin Genel Çizgileri”, Derin Ekoloji, (İzmir: Ege Yayınları, 1994), 99.

14 İsmail Gökdayı, Çevrenin Geleceği, (Ankara: Türkiye Çevre Vakfı Yayını, 1997), 176 
Sığ ekoloji, insanın tepede olduğu bir hiyerarşi üzerinden ahlaki değerleri inşa ederken, derin ekoloji bu tür bir hiyerarşiyi reddeder. Bu nedenle derin ekoloji, böyle bir hiyerarşi üzerinden oluşturulmuş etik kavrayışa dayanan hukuki kavrayışı da reddeder. Cullinan, evrende hak sahibi varlığın yalnızca insan olmadığı, yeryüzünün tüm üyelerinin yeryüzü hukukunun özneleri olduğu ve bu hukukun getirdiği sorumluluklara göre davranılması gerektiğini ortaya koyar. ${ }^{15}$ Bir nehrin taşması ve nehir kenarındaki yerleşimlere zarar vermesi durumunda, nehrin doğasında taşmanın da bulunduğunun ve hukuki sorumluluğun nehir kenarına yerleşim kuran kişilere ait olduğunun kabul edilmesi gerekir. İnsanın nehre önceliğini savunmak, insanın kendisini tepede konumlandırdığı yapay bir hiyerarşiden doğan bir yanılgıdır.

Sığ ekoloji, doğadaki varlıklara araçsal değeri bakımından değer verirken, derin ekoloji varlıkların kendi içsel değerini kabul eder. Bir canlı, insan için olan kullanım değerine bakılarak değerlendirilemez. Her canlı yeryüzünün bir üyesi olmak bakımından değerlidir. Tarımda ve tıpta insanların yararına olmayan türde bitkilerin çeşitliliğini ve fazlalığını azaltmak, insanların yararına olan türde bitkilerin çeşitliliğini ve fazlalığını artırmak sömürü ve tahakküm ilişkisi yaratmak anlamına gelir.

Sığ ekolojide çevre kirliliği insanları rahatsız ettiği sürece bir problemdir. Derin ekolojide ise çevre kirliliğinin engellenmesi için insanları rahatsı edecek düzeye gelmesine gerek yoktur. Sı̆̆ ekoloji, insanları rahatsız eden kirliliğin teknolojik olanaklar ile ortadan kaldırılabileceğini, bu kirliliğin az gelişmiş ülkelere taşınabileceğini ve bu sayede kirliliğin yoğunluğundan kaynaklanan problemlerin çözülebileceğini iddia eder. Derin ekolojiye göre ise kirlilik ihracı suçtur. Kirliliğin ötelenmesi veya yavaşlatılması için değil, engellenmesi için çalışılması gerekir. Bu hem insanlara hem insan olmayan canlılara yönelik, yani çevreye yönelik bir sorumluluktur. Derin ekolojiye göre çevre yalnızca havadan, sudan, topraktan ibaret değildir ve insansal çevreden daha geniş bir alana, tüm doğal sisteme işaret eder. ${ }^{16}$

Sığ ekoloji de derin ekoloji de insan nüfusundaki artışın doğal dengeyi bozduğunu düşünür. Fakat sığ ekoloji gelişmemiş ülkelerdeki nüfus artışının azaltılması gerektiğini düşünürken, derin ekoloji gelişmiş / gelişmemiş tüm ülkelerdeki nüfus artışının azaltılması gerektiğini savunur. Çünkü her bölgenin bir taşıma kapasitesi vardır ve bu aşılmamalıdır. ${ }^{17}$ Derin ekolojide nüfus artışının asıl sorumlusunun gene de (sanayileşmenin yarattığı olanaklar ve yayılma imkânları nedeniyle) gelişmiş ülkeler olduğu düşünülür. Gelişmiş ülkeler, doğal kaynakların ortadan kalkacak denli fazla tüketilmesinin başlıca sorumlusudur. ${ }^{18}$

15 Cormac Cullinan, Vahşi Hukuk: Bir Yeryüzü Adaleti Bildirgesi, çev. Meral Güneşdoğmuş, (İstanbul: Ayrıntı Yayınları, 2014).

16 Arne Naess, "The Shallow and The Deep, Long-Rage Ecology Movements: A Summary", Deep Ecology fort the 21st Century, Hazırlayan George Sessions, (London and Boston: Shambala Publication, 1995), 151.

17 Her bölgenin bir taşıma kapasitesi olduğu düşüncesi, küçük ölçekli toplumların yaratılması önerisinde bir kere daha gündeme gelir. David Pepper, Modern Environmentalism, (London: Routledge, 1999), 26.

18 Hasan Ünder, Çevre Felsefesi, (Ankara: Doruk Yayınları, 1996), 197. 
Kaynakların korunması, sı ̆g ekoloji için insan türünün daha fazla tüketimine olanak sağlanması açısından önemlidir. Derin ekolojik yaklaşım ise kaynakların insan kullanımına amade olmadığını öne sürer. İnsanların ihtiyaçları ile kaynakların kullanımı arasındaki ilişki, insan olmayan canlıların da gözetileceği şekilde yeniden kurulmalıdır. Kaynak sömürüsü doğaya ve canlılara karşı işlenmiş bir suçtur.

Sığ ekolojik yaklaşım için derin ekolojinin sömürüyü azaltma önerileri anlamsızdır, çünkü insanlar yaşam şartlarının düşmesine razı olmaz ve mevcut durumun en uzun şekilde nasıl sürdürülebileceğini sorarlar. Oysa derin ekolojiye göre mevcut sömürü durumu er ya da geç sona erecektir. Henüz imkân varken rahatımızdan ödün vermek ve her canlının eşit imkânlara sahip olacağı bir dünya için uğraşmak en makul seçenektir.

Sığ ekolojik yaklaşımı savunanlar, sömürünün doğanın bir gereği olduğunu, bu nedenle insan sömürüsünün de doğal olduğunu savunurlar. Kendisini doğadan ayırıp onun kullanıcısı haline getiren insanların, nasıl olup da doğadaki varlıkların tutumlarını kendi ahlak ilkeleri haline getirdiklerini görmek şaşırtıcıdır. "Savaş muhtemelen insanlar için 'doğal'dır (çok sayıda toplum çok farklı koşullar altında ve çok uzun bir tarih dönemi boyunca savaşlara karıştı), ama ben sırf doğama uygun davranacağım diye savaşa gitmem."19 Aslanın geyiği avlamasında bir zalimlik yoktur. Fakat insanın geyiği avlaması, mezbahalar üretmesi, doğayı katletmesi zalimcedir ve böyle olmasina gerek yoktur.

Derin ekolojik yaklaşım aynı zamanda kültürel olarak çeşitliliği savunur. Gelişmemiş ülkelerin Batılılaştırılmasına karşı çıkar. Yerel kültürel zenginlikler, yaşam biçimlerindeki çeşitliliğe işaret eder:

"Gelişme anlayışlarında ortaya çıkacak kültürel çeşitlilik doğayla uyumlu gelişme seçeneklerinin de artmasını sağlayacaktır. Bu anlamda doğal çeşitliliğe aykırı tek kültürlü yapılanmanın çok kültürlü bir yapıya dönüşmesi hedeflenmektedir." ${ }^{20}$

Görüldüğü gibi derin ekolojik yaklaşım insan dünyasını doğal dünyanın bir parçası olarak görmektedir. İnsan dünyasının kültürel çeşitlilik sayesinde doğal dünyanın çeşitliliğine yaklaştırılabileceğini ve böylece insan-doğa arasındaki yarılmanın da iyileştirilebileceğini düşünmektedir. Derin ekolojideki bu çoğulcu yaklaşım onun doğayla kurulması gerektiğini öne sürdüğü yeni ilişkinin tek boyutlu bir ilişki olmaması anlamına gelir.

Arne Naess ve George Sessions, derin ekolojinin ilkelerini şu şekilde formüle eder: ${ }^{21}$

1. Yeryüzündeki insanların ve insan olmayan hayatın iyi durumda olması ve serpilip gelişmesi, kendinde geçerlidir-içsel bir değere sahiptir. Bu değerler, insan olmayan dünyanın insanın amaçları için yararlı olmasından bağımsızdır.

19 Singer, Hayvan Özgürleşmesi, 304.

20 Fatih Kırışıı, "Ekolojik Sorunların Çözümünde Derin Ekoloji Yaklaşımı”, Ekonomik ve Sosyal Araştırmalar Dergisi 2 (2013): 285 .

21 Arne Naess, “Derin Ekolojinin Temelleri”, Derin Ekoloji, Der. Günseli Tamkoç, (İzmir: Ege Yayınları, 1994). 
2. Hayat formlarının zenginliği ve çeşitliliği, bu değerlerin gerçekleştirilmesine katkıda bulunur. Bu zenginlik ve çeşitlilik, aynı zamanda kendi içinde değerlidir.

3. Hayati ihtiyaçlarını karşılamak dışında, insanların bu zenginliği ve çeşitliliği azaltmaya hiçbir hakları yoktur.

4. İnsan hayatının ve kültürlerinin serpilip gelişmesi, insan nüfusunun ciddi ölçüde azaltılmasıyla mümkün olabilir. İnsan olmayan hayatın serpilip gelişmesi de daha az bir insan nüfusunu gerektirir.

5. Hali hazırda, insanın insan olmayan dünyaya müdahalesi aşırı düzeydedir ve durum kötüleşmektedir.

6. Dolayısıyla politikalar değişmelidir. Değişen politikalar, temel ekonomik, teknolojik ve ideolojik yapıları etkileyecektir. Böyle bir değişikliğin getireceği sonuç, mevcut durumdan derin bir biçimde farklı olacaktır.

7. İdeolojik değişiklik, gittikçe yükselen bir hayat standardını hedeflemekten ziyade, esas olarak hayatın niteliğini değerli kılma (içsel değer taşıyan konumlarda yer alma) yönünde olacaktır. Büyüklük/irilik ile yücelik arasındaki farka ilişkin derin bir bilinç oluşacaktır.

8. Yukarıda ifade edilen hususlara katılanlar, gerekli değişiklikleri gerçekleştirmeye alışmakla doğrudan ya da dolaylı olarak yükümlüdürler.

Arne Naess derin ekoloji görüşünü ekosofi kavramı altında ifade eder. Ekosofi, ekolojiden bir bilim değil, bilgelik olması bakımından ayrılır. Ekosofik yaklaşım doğa ile kurulan ilişkinin bir bilen/bilinen ilişkisi olmaktan çıkarak bütüncül bir kavrayışa dayanması anlamına gelir. Bilimin kısıtlayıcı çerçevesi ekosofik yaklaşımda terk edilir. Naess çoğunlukla ekosofisinin mistik ve dinsel bir öğreti olduğu gerekçesiyle eleştirilmiştir. Fakat burada dikkat edilmesi gereken husus, ekosofinin doğayı geleneksel özne-nesne kalıpları ile ele almayı bırakarak yeni bir ilişkinin çerçevesinde değerlendirmesidir. Başka deyişle ekosofi gerçekten de bilimsel bir nitelik taşımaz. Fakat ekosofinin değeri tam da burada yatar. Doğayı nesne olmaktan çıkarıp onu içerisindeki tüm tekil özneleri kapsayan bir bütüncül özne olarak ele almak demek, kurulan ilişkinin de bilinen nesne ile bilen özne ilişkisinden çıkması demektir. "İnsan ile doğa bütünleştirilerek doğa Gaia olarak kişileştirilmekte, doğaya bir benlik verilmektedir." 22 Naess’in ekosofisinin odağı, doğa ile ilişkimizi biçimlendirecek yeni ahlaki ölçütler sunmanın ötesinde, bu ilişkinin kendisini yeniden tanımlamak, doğaya ve gerçeklik duyumuza dair farklı bir deneyim oluşturmaktır. ${ }^{23}$ İnsan olmanın, toplum olmanın, yaşamanın yeni bir anlamını inşa etmektir. Nietzsche, bir decadance (çöküş) durumundan çıkmanın ancak yeni değerlerin inşa edilmesi ile ve bu değerlerin

22 Hasan Yaylı, Vasfiye Çelik, “Çevre Sorunlarının Çözümü İçin Radikal Bir Öneri: Derin Ekoloji”, Selçuk Üniversitesi Sosyal Bilimler Enstitüsü Dergisi 26 (2011): 372.

23 E. Cavazza, "Environmental Ethics as a Question of Environmental Ontology: Naess' Ecosophy T and Buddhist Traditions", De Ethica, A Journal of Philosophical, Theological and Applied Ethics Vol 1:2 (2014): 28. 
güç kazanması ile mümkün olduğunu öne sürmüştü. ${ }^{24}$ Fakat bu yeniden değerlendirme faaliyeti a'ya b demeye başlamanın ötesinde, a ile b'nin anlamlarında toptan bir başkalaşmaya gerek duyar. Naess'in bilimsel tavrı bir kenarda tutmakla beraber, doğa ile ilişkide belirleyici rolü canlı merkezli bir tutuma vermesinin önemi tam da burada yatmaktadır.

Naess' in ekosofisinin temel ilkeleri kendini gerçekleştirme ve biyosferik eşitliktir. ${ }^{25}$ Kendini gerçekleştirme, sahip olunan potansiyeli hiçbir engelle karşılaşmaksızın veya karşılaşılan engellerin üstesinden gelerek ortaya koyabilmektir. Bu düşüncede ondaki Budist felsefenin etkisini görürüz. Naess bir adım daha atar ve kendini gerçekleştirmede ortaya koyulan potansiyelin diğer varlıklarla olan bir ayrım temelinden oluşmadığını, benlik ile ötekiliğin birbirine bağlı olduğunu öne sürer. Böylece doğayla veya doğadaki varlıklarla olan karşlıklı bağımlılığa işaret eder. Bu bağlılık görmezden gelindiği sürece kendini gerçekleştirmek ve ekosofik bir konuma yerleşmek mümkün olmayacaktır. Elbette kendini gerçekleştirme yalnızca insana özgü değil, tüm canlılara özgüdür. Bu nedenle kendini gerçekleştirme ile biyosferik eşitlik ilkeleri yakın ilişki içerisindedir. Kendini bulmanın en üst noktası çeşitlilikteki birlik duygusunu deneyimlemek, en alt noktası ise kişinin her şeye yabancılaştığı egoizmdir. ${ }^{26}$ Dolayısıyla kendini gerçekleştirmenin en üst noktasında insanın doğanın her bir parçasını uzvu olarak duyumsadığı, aynı şekilde kendisini de doğanın bir uzvu olarak duyumsadığı bir deneyim söz konusudur. Bu deneyim mistik bir aydınlanmayı gerektirir gibi görünse de Devall'a göre bu deneyim kişinin kendisini mekân ile özdeşleşmeye eğitmesi sayesinde mümkün olur. ${ }^{27}$ Burada sanırım ne ölçülebilir bir zaman ve mekân anlayışına ne de sembolik dile sahip olan avcı toplayıcıların yaşam biçimleri söz konusu edilebilir. İnsanın duygu ve düşüncelerinin sembolleştirilerek bölünmesi doğadan yabancılaşmanın temel nedenlerinden biridir. Bu sembolleştirmeye yol açan şeyin tarımdan kaynaklanan mülkiyet ilişkileri ile zamanın ve mekânın bölünmesi ve sembolik dilin yaratılması olduğundan söz etmiştik. Ben ve Ben olmayan ayrımının doğması tarımla beraber başlayan 10 bin yıllık bir dönemin eseri ise insanlığın çok daha uzun zamanlar boyunca farklı bir deneyim içerisinde olması, ekosofik yaklaşımın benimsenmesinin imkânsız olmadığını gözler önüne serer.

Derin ekoloji mekanik dünya anlayışının yerini ekolojik anlayışa bırakacağını savunur. Bunun için sade yaşamak, sınırsız büyüme arzusuna son vermek, küçük ölçekli topluluklar kurmak, politikayı insan, toplum ve doğanın karşılıklı ilişkisi olarak düşünmek, şiddeti tamamen reddetmek ve sosyal sorumluluk ve yardımlaşma projelerine ağılık vermek, yerli bitki ve hayvanların kendi alanlarında yaşamalarını sağlamak ve alanlarını iyileştirmek gibi öneriler öne sürer. Bu önerileri gözeterek 1980 yılında Dave Foreman tarafından Earth First isimli bir oluşum kurulmuştur. "Earth First'ün en belirgin söylemi toplumsal hayatın ekolojik öncelikler kapsamında yeniden düzenlenmesi olmuştur." ${ }^{28}$ Bu kuruluşun çözüme yönelik önerileri ve kazandıkları kamuoyu desteği dikkate şayandır. ${ }^{29}$ Derin ekolojik yaklaşımı eylem boyutuna geçiren tek kuruluş Earth

24 Friedrich Nietzsche, Gü̧̧ İstenci, çev. Nilüfer Epçeli, (İstanbul: Say Yayınları, 2017).

25 Tuncay Önder, Ekoloji, Toplum ve Siyaset, (Ankara: Odak Yayınları, 2003). 157.

26 Bill Devall, "Ekolojik Benliğimiz”, Derin Ekoloji, Der. Günseli Tamkoç, (İzmir: Ege Yayınları, 1994), 56.

27 Devall, "Ekolojik Benliğimiz”, 55.

28 Fatih Kırışık, “Ekolojik Sorunların Çözümünde Derin Ekoloji Yaklaşımı”, 294.

29 Mehmet Akif Özer, "Derin Ekoloji”, Çă̆daş Yerel Yönetimler 4 (2001): 76. 
First değildir. Dünyanın pek çok yerinde derin ekolojinin sistemleştirerek ilkelerini sunduğu tavrın örneklerini görmek mümkündür. "Çok diren, az boyun eğ” sloganının da gösterdiği gibi derin ekolojiyi benimseyenler, insanların ve toplumların teknolojik araçların kullanımı ile doğayı sömürgeleştirmesine direnmiş, bu sömürgeleştirmenin kaynağını oluşturan ilerleme yanılgısına karşı çıkmışlardır. ${ }^{30}$

Derin ekolojik yaklaşım elbette ki kusursuz değildir. Fakat derin ekoloji, kendisine yöneltilen eleştirileri dikkate alarak iyileşme potansiyeline sahiptir. Her şeyden önce derin ekolojik yaklaşımın önerdiği şey, yani doğaya karşı tavrımızda radikal bir değişikliğe giderek kendimizi doğanın sahibi değil, bir ögesi olarak konumlandırmamız gereği görmezden gelinemez. Özellikle doğa ile olan ilişkimiz bu denli bir yabancılaşma içindeyken ve bu ilişkiyi mevcut haliyle sürdürmenin getireceği korkunç sonuçlar apaçık bir şekilde karşımızda duruyorken, derin ekolojinin önerdiği radikallikte bir biyosantrizmin olanağını görmezden gelemeyiz.

Derin ekolojiye yöneltilen eleştirilere kısaca da olsa değinmek bu tutumdaki sorunları yanları düşünmek bakımından bize iyileştirici bir perspektif sunar:

Her şeyden önce derin ekoloji felsefi-bilimsel bir öneri sunmaktan ziyade mistik bir inanç yaratmakla suçlanmıştır. Fakat bu suçlamanın felsefeyi ve bilimi özne-nesne ikiliğine dayandıran ve düşünceyi antroposantrik öncelikle inşa eden bir düşünüşün ürünü olduğunu göstermiştik ve derin ekolojiyi tam da bu sebeple önemsememiz gerektiğini öne sürmüştük. Derin ekolojinin kavrayışımızı biyosantrik bir odağa kaydırmamızı mümkün kılacak önerileri ne ütopik ne de mistiktir. Bu önerilerin meşruiyetini insanın doğayla kurduğu ilişki özelinde inşa etmesi onun bilimsel değerinden çok şey eksiltse de felsefi değerinden bir şey eksiltmemektedir.

Bir başka eleştiri, derin ekolojinin doğadaki her varlığın biyosferik eşitliğini öne sürerken antroposantrik bir biçimde insansal dünyaya ait hak, değer gibi kategorileri doğaya atfetmesine yöneliktir. Bu anlamda derin ekoloji biyosantrizmi tam da insan merkezci bir konumdan savunmaktadır. ${ }^{31}$

Ayrıca derin ekolojinin insanı doğadan ayırdığı ve tam da karşı olduğu şeyi yaklaşımının temeline aldığı iddia edilmiştir. Benzer şekilde doğanın da bütünüyle doğal olduğunu ve tarihsel toplumsal bir süreçten muaf olduğunu varsayması nedeniyle eleştirilmiştir.

$\mathrm{Bu}$ eleştirilerden en önemlisi de derin ekolojinin toplumsallık boyutunu göz ardı etmiş olmasıdır. Buna göre derin ekolojinin doğanın sömürüsünde etkili bir payı olan ve biyolojik eşitliğin sağlanmasının önündeki en büyük engel olan toplumsal ve ekonomik eşitsizlikleri göz ardı etmiştir. ${ }^{32}$ Bookchin'e göre sorunun kaynağı toplumsaldır ve öncelikli olarak toplumsal yapılanmaya odaklanmak ve konfederasyonal topluluklar oluşturmanın imkânını sorgulamak

30 Bill Devall, "Ekoloji Politikası", Derin Ekoloji, Der. Günseli Tamkoç, (İzmir: Ege Yayınları, 1994), 20.

31 Bilge Kağan Şakacı, "Değer Kavramı Ekseninde Derin Ekoloji Yaklaşımının Çözümlenmesi”, Mülkiye Dergisi 37 (2013): 25.

32 Carolyn Merchant, Radical Ecology, (New York: Routledge, 1992), 103. 
gerekir. ${ }^{33}$ Bununla ilişki olarak derin ekolojinin ayrıca, nüfus fazlalığını tüketim aşırılığının asıl nedeni olarak ilan etmesi eleştirilmiştir. Doğa sömürüsünün asıl nedeni nüfus fazlalığı değil, tüketim fazlalığı ve eşitsiz gelişme ile sanayileşmedir.

Bir diğer eleştiri derin ekolojideki Spinozacı, Budizmci, avcı toplayıcı, romantik, Heideggerci, 1960ların karşı kültürü, Kızılderili kültürü vd. ögelerin onu düşünsel bir karmaşa sunan eklektik bir sistem haline getirmesine yöneliktir. ${ }^{34}$

\section{Sonuç}

Derin ekolojik yaklaşım, çevreyi koruma niyetini insanı ve toplumu dönüştürücü önerilerle ortaya koyduğu için radikal bir harekettir. Çevre sorunlarının iyileştirilmesinin her şeyden önce yeniden ekolojik bütünlüğü kavramak ile mümkün olduğunu düşünür. Bunu sağlayacak olan ise mevcut üretim-tüketim ilişkilerinin reddedilmesi ve mevcut yapılanmayı sorgulayan yeni paradigmaların geliştirilmesidir. Çünkü çevreye verilen zararları ortadan kaldırmak yeterli değildir. Her şeyden önce önleyici bir yaklaşımı savunmak ve zararlara neden olan tutumları sorgulamak ve değiştirmek gerekir.

Derin ekolojinin yeşil bir toplumun kurulma imkânına yönelik olumlu tavrının ve bunu sağlamak için getirdiği alternatif görüşlerin, çevre kirliliğinin, türlerin yok oluşunun, buzulların erimesinin görmezden gelinemez bir hale geldiği günümüzde ciddiye alınması son derece zorunludur. Derin ekolojik hareket, dünyayı 'kurtarmanın’ toptan bir çözümünü sunmaz. Derin ekolojinin önerdiği radikallikte bir biyosantrizm, çevre korumacı bir tutum olmanın ötesinde bir dünya görüşüdür. İnsan-doğa ikiliğinin ötesine geçer ve yeryüzündeki canlılığa yönelik her kastın bizzat kendi varlığımıza yönelik olduğunu öne sürer. Doğa’yı Ben’in uzantısı olarak tarif eder ve öz-gerçekleştirim etiği gereği doğaya olan sorumluluğumuzdan söz eder.

Derin ekolojiye yöneltilen mistiklik suçlamaları, bu hareketteki Batılılaşmaya, modernleşmeye, insan merkezciliğe, bilimsel bilginin ikincilliğine yönelik düşüncelerden kaynaklanır. Sezgisel bilginin önceliğine ve insanın doğayla olan bütünleyici ilişkisini yeniden kurması gereğine dair düşünceleri mistiklik denilerek bir köşeye atılamaz. Çünkü gerçekliğe dair anlamlı bir söylem üretme çabası olarak felsefe, bilimsel olmaya indirgenemez. Felsefe, olaylara derinlemesine bakabilmek, bu bakışı yönlendiren varsayımları sorgulayabilmek demektir. Derin ekoloji biyosantrizme yaptığı vurgu ile, insan varlıklarının ancak diğer canlı varlıkların çıkarlarını ve haklarını gözetmesiyle kendilerini gerçekleştirebileceklerine işaret eder. Antroposantrik yaklaşımların çevre sorunlarının iyileştirilmesine bir katkısı olmadığını, mekanistik dünya görüşüne dayanan eski paradigmanın bütünüyle reddedilmesi gerektiğine vurgu yapar.

Yalnızca bir 'dışarısı' olarak çevrenin iyileştirilmesi adına değil, kendi varoluşumuz adına da biyosantrik bir perspektifi benimsememizin gerekli olduğunu düşünüyorum. Doğaya yönelik sömürü ve tahakküm ilişkisinin çözülmesi ve yerini biyosferik eşitlik ilkesine bırakması ile aynı

33 Murray Bookchin, Social Ecology and Communalism, (Edinburg: AK Press, 2006), 97-110.

34 Murray Bookchin, Toplumu Yeniden Kurmak, çev. Kaya Şahin, (İstanbul: Metis Yayınları, 1999), 24-25. 
zamanda insanın insana yönelik sömürü ve tahakkümünü aşmaya yönelik bir adım atılacaktır. Yeryüzünün evimiz olmanın ötesinde, tüm bedenleri kendinde kapsayan bir beden olarak görülmesi, hak kavramının insan olmayan varlıkları da kapsayacak şekilde genişletilmesi gerekir.

Çevreyi Öteki olarak görmekten kaynaklanan tahakküm ilişkileri ve yabancılaşma, bireysel mücadeleler sayesinde aşılacaktır. Bunun için derin ekoloji, bireylerin gönüllü olarak sade yaşamayı benimsemesine vurgu yapar. Otto Weininger'in belirttiği gibi, gerçek bir özgürlük için her şeyden önce bireysel olarak savaş vermek gerekir. ${ }^{35}$ Fakat derin ekolojinin yalnızca bir söylem değil, bir hareket de olduğu gözden kaçırılmamalıdır. Bu nedenle bireylerin özgürleşme taleplerini, derin ekolojinin ilkelerini gözeterek bir eylem alanı oluşturma talepleri izlemelidir. $\mathrm{Bu}$ ilkeler mutlak olmadığı gibi mutlak bir itaati de gerektirmez. Üstelik derin ekolojik biyosantrizm pek çok yönden sorunlu içerikler taşıyor olabilir. Buna rağmen insanın doğa ile ilişkisi içerisinde, bu ilişkiyi iyileştirdiği, bir bütün olarak yeryüzünü gözettiği ölçüde kendisini gerçekleştirebileceği iddiaları ciddiye almaya değerdir.

Hakem Değerlendirmesi: Dış bağımsız.

Çıkar Çatışması: Yazar çkar çatış̧ması bildirmemiștir.

Finansal Destek: Yazar bu çalışma için finansal destek almadığını beyan etmiştir.

Peer-review: Externally peer-reviewed.

Conflict of Interest: The author has no conflict of interest to declare.

Grant Support: The author declared that this study has received no financial support.

\section{Kaynaklar}

Aquinas, Thomas. The Summa Theologica, Translated by Fathers of The English Dominican Province, erişim 30 Nisan 2020, (http://www.documentacatholicaomnia.eu/03d/1225-1274,_Thomas_Aquinas,_ Summa_Theologiae_[2],_EN.pdf) .

Bookchin, Murray. Özgürlüğün Ekolojisi: Hiyerarşinin Ortaya Çıkışı ve Çözülüşü. Çeviren AlevTürker. İstanbul: Ayrıntı Yayınları, 1994.

Bookchin, Murray. Toplumu Yeniden Kurmak. Çeviren Kaya Şahin. İstanbul: Metis Yayınları, 1999.

Bookchin, Murray. Social Ecology and Communalism. Edinburg: AK Press, 2006.

Cavazza, E. "Environmental Ethics as a Question of Environmental Ontology: Naess' Ecosophy T and Buddhist Traditions". De Ethica: A Journal of Philosophical, Theological and Applied Ethics Vol 1:2 (2014).

Cullinan, Cormac. Vahşi Hukuk: Bir Yeryüzü Adaleti Bildirgesi. Çeviren Meral Güneşdoğmuş. İstanbul: Ayrıntı Yayınları, 2014.

Devall, Bill. “Ekolojik Benliğimiz”. Derin Ekoloji. Derleyen Günseli Tamkoç. İzmir: Ege Yayınları, 1994.

Devall, Bill. “Ekoloji Politikası”. Derin Ekoloji. Derleyen Günseli Tamkoç. İzmir: Ege Yayınları, 1994.

Freud, Sigmund. The Future of an Illusion. New York: 1955.

Gökdayı, İsmail. Çevrenin Geleceği. Ankara: Türkiye Çevre Vakfı Yayını. 1997.

35 Otto Weininger, Söz Kalıntıları, çev. Abdülbaki Güçlü, (Ankara: Pharmakon Yayınları, 2014), 211. 
Kırışık, Fatih. “Ekolojik Sorunların Çözümünde Derin Ekoloji Yaklaşımı”. Ekonomik ve Sosyal Araştırmalar Dergisi 2 (2013): 279-303.

Kuyaş, Nilüfer. Thomas S. Kuhn'un Bilimsel Devrimlerin Yapısı adlı kitabına sunuş. İstanbul: Kırmızı Yayınları, 2005.

Leopold, Aldo. A Sand County Almanac: With Essays on Conservation From Round River. New York: Ballantine Books, 1970.

McShane, Katie. "Environmental Ethics: An Overview”. Philosophy Compass 413 (2009): 407-420.

Merchant, Carolyn. Radical Ecology. New York: Routledge, 1992.

Naess, Arne. “Derin Ekolojinin Temelleri”. Derin Ekoloji. Derleyen Günseli Tamkoç. İzmir: Ege Yayınları, 1994.

Naess, Arne. "The Shallow and The Deep, Long-Rage Ecology Movements: A Summary", Deep Ecology fort the 21st Century. Hazırlayan George Sessions. London and Boston: Shambala Publication, 1995.

Nietzsche, Friedrich. Güç İstenci. Çeviren Nilüfer Epçeli. İstanbul: Say Yayınları, 2017.

Önder, Tuncay. Ekoloji, Toplum ve Siyaset. Ankara: Odak Yayınları, 2003.

Özer, Mehmet Akif. “Derin Ekoloji”. Çăgdaş Yerel Yönetimler 4 (2001).

Pepper, David. Modern Environmentalism. London: Routledge, 1999.

Session, George. Deep Ecology For The 21st Century. Boston: Shambhala, 1995.

Singer, Peter. Hayvan Özgürleşmesi. Çeviren Hayrullah Doğan. İstanbul: Ayrıntı Yayınları, İstanbul, 2005.

Şakacı, Bilge Kağan. “Değer Kavramı Ekseninde Derin Ekoloji Yaklaşımının Çözümlenmesi”. Mülkiye Dergisi 37 (2013): 9-29.

Tamkoç, Günseli. “Derin Ekolojinin Genel Çizgileri”. Derin Ekoloji. İzmir: Ege Yayınları, 1994.

Ünder, Hasan. Çevre Felsefesi. Ankara: Doruk Yayınları, 1996.

Ünsalan, Fehmi. “Küresel Ekolojik Kriz ve Felsefe: Paradigmadan Kaçış Mümkün Mü?”. Alternatif Politika 1 (2019): 86-112.

Yaylı Hasan, Çelik Vasfiye. "Çevre Sorunlarının Çözümü İçin Radikal Bir Öneri: Derin Ekoloji”. Selçuk Üniversitesi Sosyal Bilimler Enstitüsü Dergisi 26 (2011).

Zerzan, John. Gelecekteki İlkel. Çeviren Cemal Atila. İstanbul: Kaos Yayınları, 2018.

Weininger, Otto. Söz Kalıntıları. Çeviren Abdülbaki Güçlü. Ankara: Pharmakon Yayınları, 2014. 
